\title{
ATTRIBUTES RELATED TO SEASONAL HERBAGE GROWTH IN WHITE CLOVER
}

\author{
Omar Scheneiter*; Beatriz Rosso; Mauro Corletto \\ INTA, Estación Experimental Agropecuaria Pergamino \\ Avda. Frondizi km 4.5, B2700WAA, Pergamino, Buenos Aires, Argentina \\ *Corresponding author <oscheneiter@pergamino.inta.gov.ar>
}

\begin{abstract}
When breeding temperate forage species is investigated, some attributes such as herbage accumulation and seasonal growth patterns have to be considered. To modify some of these traits, knowledge of the detailed process might be useful. In order to evaluate seasonal growth of contrasting white clover populations an experiment was carried out. Treatments were five cultivars and three local populations collected in Argentina. Weekly measures were taken during each season to calculate leaf appearance and flower appearance rates, stolon growing rate and dry matter (DM) net accumulation. Different germplasm of this species have different mechanisms for DM accumulation. Leaf size, more than leaf appearance rate, was the variable with most differences among germplasm and mostly related to dry matter accumulation. During spring and summer, inflorescences production had important effects on growing stolon rate, and differences among germplasm were evident. Some local populations showed favourable attributes that could be useful for breeding.
\end{abstract}

Key words: Trifolium repens L., germplasm, leaves, inflorescences, stolon growth

\section{ATRIBUTOS RELACIONADOSAO CRESCIMENTOSAZONALDE FORRAGEMEM TREVO BRANCO}

\begin{abstract}
RESUMO: Quando o melhoramento de forrageiras de clima temperado é investigado, alguns atributos tais como acúmulo de forragem e padrões de crescimento sazonal devem ser considerados. Para a modificação de alguns desses caracteres, o conhecimento detalhado destes processos pode ser útil. No sentido de avaliar o crescimento sazonal de populações contrastantes de trevo branco, um experimento foi conduzido. Os tratamentos consistiram de cinco cultivares e três populações nativas coletadas na Argentina. Medições semanais foram realizadas durante cada estação do ano para cálculo das taxas de aparecimento de folhas e flores, taxa de crescimento de estolões e acúmulo de matéria seca. Germoplasmas distintos para essa espécie apresentam mecanismos distintos para acúmulo de matéria seca. A característica de tamanho de folha, mais do que a taxa de aparecimento de folha, foi a variável analisada que mostrou as maiores diferenças entre os germoplasmas analisados, além de estar mais relacionada ao acúmulo de matéria seca. Durante a primavera e verão, a produção de inflorescências mostrou efeito importante na taxa de crescimento de estolões e diferenças entre os germoplasmas foram evidentes. Algumas das populações nativas apresentaram atributos favoráveis que podem ser úteis no melhoramento.

Palavras-chave: Trifolium repens L., germoplasma, folhas, inflorescência, crescimento de estolões
\end{abstract}

\section{INTRODUCTION}

White clover (Trifolium repens L.) is a major forage legume in temperate grassland regions worldwide. In Argentina, nearly 300.000 ha are sown annually and the land where this legume is present in the Humid Pampa region was estimated in 4.9-5.4 M ha. Many cultivars have been released all over the world and genetic improvement has been possible due to improved evaluation methods and identification of parents with superior breeding value (Woodfield \& Caradus, 1994). Germplasm collections are important sources of variation for breeding programs, but they must be properly characterized to be effectively utilized. To develop new forage cultivars, total herbage accumulation, seasonal growth pattern, forage quality and persistence must be considered. To modify some of these traits, the knowledge of detailed processes not commonly used in breeding programs might be worthwhile since they are complementary to seasonal pattern of growth and herbage accumulation.

Some differences in seasonal growth pattern and persistence of white clover germplasm have been observed in the north of Buenos Aires Province, regardless of leaflet size. In spring and summer, when leaf represents on average $58 \%$ of the aerial stolon 
growth, some differences among cultivars on stolon growth were related to earliness and intensity of resources allocation to reproductive sinks (Scheneiter \& Pagano, 2001). During autumn and winter, when leaf represents on average $75 \%$ of the aerial stolon growth, differences were mainly related to the inherent germplasm ability to grow at low temperatures. However, at present, it is difficult to assess the relative importance of processes like leaf and flower appearance rates and sizes on white clover growth rates. Thus, morphogenetic characterization could add new and better tools to assist white clover breeding programs.

"Path analysis" is a statistical method that has been used since the sixties to study causal relationships among grain yield and yield components. This method has proved to be useful in forage species to describe the relationship among temperature and seed emergence (Hill et al., 1985). "Path analysis" splits total correlation between response variable and predictive variable, and between direct and indirect effects. The use of this kind of analysis in agricultural sciences allows to gain the insights from the results of correlation matrices.

The objective of this study was to evaluate seasonal growth of contrasting white clover germplasm through different attributes related to leaf and inflorescence production and growth.

\section{MATERIAL AND METHODS}

\section{Treatments}

Treatments consisted of 5 cultivars and 3 local populations collected in Argentina. The main characteristics of each cultivar were:

Espanso - cultivar originated from Lodi (Italy), selected for drought tolerance (Caradus \& Woodfield, 1997): large-leaved, high stolon density and delayed flowering;

Gapp 596 - cultivar originated from U.S.A.: largeleaved, high forage production in autumn and winter, and lower seed production than Lucero Plus INTA (Bertín, 2002);

Grassland Kopu - cultivar from New Zealand: medium-leaved, high forage production in summer and winter;

Haifa - cultivar selected in Australia from germplasm collected in the north of Israel: long-leaved, heat tolerant, early flowering and good winter growth (Caradus \& Woodfield, 1997);

Lucero Plus INTA - cultivar originated in Argentina from selection in El Lucero MAG: long-leaved, high growing point density, early flowering, high winter and spring forage production (Pagano, 1999; Pagano \& Scheneiter, 2000);

According to Rosso \& Pagano (2001a), the main characteristics of local populations conserved at INTA EEA Pergamino Active Germplasm Bank were:

TR 09 - collected in Santa Fe province, $32^{\circ} 01^{\prime}$ S, $1^{\circ} 10^{\prime}$ $\mathrm{W}$, frequently defoliated, early flowering and low stolon density.

TR 38 - collected in Buenos Aires province, $36^{\circ} 11^{\prime} \mathrm{S}$, $61^{\circ} 06^{\prime} \mathrm{W}$, grazed site, small leaves, and low plant height.

TR 52 - collected in Cordoba province, $32^{\circ} 28^{\prime} \mathrm{S}$, $63^{\circ} 18^{\prime} \mathrm{W}$, grazed site, long leaves, high spring forage production.

\section{Site}

The experiment was sown at Pergamino

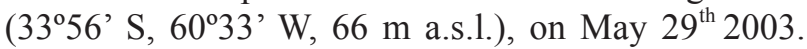
Soil was classified as typic Argiudol series Pergamino. White clover was not present in previous years. Prior to sowing, $150 \mathrm{~kg} \mathrm{ha}^{-1}$ of $0-46-0$ was incorporated. Long term rainfall of the experimental site is $975 \mathrm{~mm}$ year ${ }^{-1}$ and long term mean air temperature is $10.4^{\circ} \mathrm{C}$ in winter (Jun-Ago) and $22.7^{\circ} \mathrm{C}$ in summer (DecFeb).

\section{Measurements}

From summer 2004 to spring of the same year, weekly measurements were taken in each season (three weeks in the summer, autumn and winter and four weeks in the spring). In each treatment, 10 stolons per experimental unit were selected randomly, and properly identified in the sward with pins. At each measurement period, the first expanded leaf was tagged with non toxic red paint. Every week, new expanded leaves as well as dead ones were recorded. Leaf area of each recorded leaf was visually estimated in the field according to a scale proposed by Williams et al. (1964). In addition, in a set of leaves ( $\sim 5 \mathrm{~g}$ of fresh leaves per experimental unit), leaf area was determined using a leaf area meter (Licor LI 3100) and its specific leaf weight was calculated as the ratio of leaf weight (on dry matter-DM- basis) and leaf area (leaflet plus petiole). Growing point density was evaluated weekly in two frames of $0.06 \mathrm{~m}^{2}$ per experimental unit as the number of stolon tips with at least two leaves per area unit. In each stolon, inflorescences were counted and weighed during spring, summer and winter.

Measured variables were used to calculate leaf appearance rate (leaves per growing point per week), flower appearance rate (flowers per growing point per week), stolon growing rate (mg DM per growing point 
per day) and DM net accumulation (mg DM per growing point).

\section{Experimental design and procedure}

Treatments were arranged in a complete randomized block design with four replicates. Plots had six rows (white clover and tall fescue were sown in alternate rows), $4.0 \mathrm{~m}$ in length and $0.2 \mathrm{~m}$ among rows (total area $4.8 \mathrm{~m}^{2}$ ).

Treatments were defoliated to $5 \mathrm{~cm}$ height when they reached 20 to $30 \mathrm{~cm}$ height on average. Measurements in each season started ten days after defoliation.

\section{Experimental statistical analysis}

Results were analyzed by ANOVA Procedure of the SAS System (1989) at each measurement period. When differences among treatments were detected, means were compared using LSD $(p<0.05)$.

In addition, causal relations were established using "Path analysis", splitting total correlation between response variable and predictive variable, and between direct and indirect effects. Theoretical fundamentals and description of the statistical methodology were described in SAS System (1989), Dofing \& Knight (1992) and Williams et al. (1990). Data for "Path analysis" were analyzed by CALIS Procedure of the SAS System (1989).

\section{RESULTS AND DISCUSSION}

For convenience, results were clustered in reproductive (spring and summer) and vegetative stage (autumn and winter).

\section{Reproductive stage}

Leaf and inflorescence appearance rates and leaf size There were no differences among germplasm in leaf appearance rates in any season (Table 1). Means were 0.62 and 0.97 leaf per growing point per week in the spring and summer, respectively. Lawson et al. (1997) did not find any differences between medium and large leaf cultivars in summer, and showed that leaf appearance rate was similar to the one found in this experiment. In addition, Acuña et al. (1997) and Elgersma \& Fengrui (1997) did not find differences among germplasm between spring and summer for this variable although they reported higher values than those found in this experiment.

There were differences in inflorescence appearance rates (Table 1) similar to those found by Rosso \& Pagano (2001b), although Elgersma \& Li (1997) did not find any. In spring, no relationship between leaf and inflorescence appearance rates was observed, whereas in summer, both variables were correlated positively in the first week $(p<0.001$, $r: 0.58)$ and negatively in the second week $(p<0.001$, $r: 0.50)$. Previous experiments indicated an inhibitory effect of inflorescence appearance on vegetative growth. Thomas (1987) suggested that different inhibitory influences of flowering on vegetative growth could be associated with the state of flower development, that is pre-emergence, post-emergence and postfertilization. Contradictory results between first and second week could be associated with Thomas's hypothesis.

In spring, cultivars Haifa and Espanso exhibited the highest leaf area, whereas G. Kopu and local

Table 1 - Leaf and inflorescence appearance rates and leaf area in white clover germplasm during the reproductive stage. Values averaged all over the season.

\begin{tabular}{|c|c|c|c|c|c|c|}
\hline \multirow{3}{*}{ Germplasm } & \multicolumn{3}{|c|}{ Spring } & \multicolumn{3}{|c|}{ Summer } \\
\hline & $\begin{array}{l}\text { Leaf appearance } \\
\text { rate }\end{array}$ & $\begin{array}{c}\text { Inflorescence } \\
\text { appearance rate }\end{array}$ & Leaf area & $\begin{array}{l}\text { Leaf Appearance } \\
\text { rate }\end{array}$ & $\begin{array}{c}\text { Inflorescence } \\
\text { Appearance rate }\end{array}$ & Leaf area \\
\hline & $\begin{array}{l}\text { leaves per growing } \\
\text { point per week }\end{array}$ & $\begin{array}{c}\text { flowers per growing } \\
\text { point per week }\end{array}$ & $\mathrm{cm}^{2}$ per leaf & $\begin{array}{l}\text { leaves per growing } \\
\text { point per week }\end{array}$ & $\begin{array}{c}\text { flowers per growing } \\
\text { point per week }\end{array}$ & $\mathrm{cm}^{2}$ per leaf \\
\hline $\begin{array}{l}\text { Lucero P. } \\
\text { INTA }\end{array}$ & 0.69 & 0.44 & 4.8 & 1.04 & 0.36 & 3.4 \\
\hline Haifa & 0.67 & 0.48 & 5.3 & 0.90 & 0.18 & 3.2 \\
\hline G. Kopu & 0.65 & 0.41 & 4.0 & 0.86 & 0.23 & 2.3 \\
\hline TR 38 & 0.62 & 0.51 & 4.2 & 0.94 & 0.24 & 3.1 \\
\hline Espanso & 0.61 & 0.24 & 5.3 & 1.09 & 0.22 & 3.2 \\
\hline TR 52 & 0.61 & 0.32 & 4.1 & 1.02 & 0.08 & 2.8 \\
\hline Gapp 596 & 0.58 & 0.30 & 4.9 & 0.98 & 0.33 & 3.1 \\
\hline TR 09 & 0.57 & 0.47 & 4.2 & 0.90 & 0.32 & 3.2 \\
\hline $\begin{array}{l}\text { Significance } \\
\text { LSD }\end{array}$ & NS & $\begin{array}{c}p<0.001 \\
0.12\end{array}$ & $\begin{array}{c}p<0.001 \\
0.65\end{array}$ & NS & $\begin{array}{c}p<0.001 \\
0.11\end{array}$ & $\begin{array}{c}p<0.01 \\
0.54\end{array}$ \\
\hline
\end{tabular}

*NS, not significant; LSD, least significant difference $(p<0.05)$. 
populations exhibited the lowest (Table 1). In summer, leaf area was smaller than in spring time. Water stress in summer, which usually occurs in Pergamino, could be one of the causes for the reduced leaf area when compared with spring (Frame, 1998). Another cause could be the more upright large-leaved forms in the tall spring canopies in infrequently defoliated swards. G. Kopu and TR 09 exhibited the smallest leaf size.

\section{Dry matter accumulation}

Highest values of dry matter net accumulation during spring were obtained with Haifa and Lucero Plus INTA and the lowest with TR 52 (Table 2). Stolon growing rates rose, on average, from $5.1 \mathrm{mg} \mathrm{DM}$ per growing point per day in the first measurement period to $7.2 \mathrm{mg} \mathrm{DM}$ per growing point per day in the second one (Table 3), but remained steady afterwards. There were only small differences among treatments, except in mid spring when TR 52 grew at lower rate (2.2 $\mathrm{mg}$ DM per growing point per day) than the rest of the treatments.

Path analysis results showed that, in three of four periods in spring, leaf area had stronger direct effect on stolon growing rates than on leaf appearance rate (Table 4). There were no relationships among leaf and inflorescence appearance rate, inflorescence appearance rate and stolon growing rates and inflorescence weight and stolon growing rates. Such results suggested that there was not a general model of growth, but different mechanisms of DM accumulation for treatments. For example, Espanso, a cultivar with high leaf growth rate and low partition to reproductive sinks (Rosso \& Pagano, 2001b), had low DM

Table 2 - Dry matter net accumulation in spring and summer with different white clover germplasm.

\begin{tabular}{|c|c|c|c|c|c|c|c|}
\hline \multirow[b]{2}{*}{ Germplasm } & \multicolumn{4}{|c|}{ Spring } & \multicolumn{3}{|c|}{ Summer } \\
\hline & $\begin{array}{c}\text { Oct. } 13- \\
20\end{array}$ & $\begin{array}{c}\text { Oct. } 21- \\
27\end{array}$ & $\begin{array}{c}\text { Oct. } 28- \\
\text { Nov. } 3\end{array}$ & Nov. $4-10$ & Dec. $22-30$ & $\begin{array}{c}\text { Dec. } 31- \\
\text { Jan. } 6\end{array}$ & Jan. 7-13 \\
\hline & $\ldots$ & 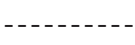 & 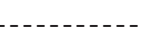 & mg DM per & point - & & \\
\hline $\begin{array}{l}\text { Lucero P. } \\
\text { INTA }\end{array}$ & 35.0 & 86.8 & 152.4 & 205.3 & 48.6 & 82.2 & 125.0 \\
\hline Haifa & 43.5 & 97.8 & 155.9 & 220.0 & 20.9 & 55.4 & 77.7 \\
\hline G. Kopu & 40.6 & 84.0 & 127.0 & 189.5 & 28.2 & 53.4 & 54.1 \\
\hline TR 38 & 35.5 & 90.9 & 134.4 & 172.8 & 37.3 & 70.4 & 84.1 \\
\hline Espanso & 31.9 & 74.4 & 115.4 & 167.7 & 40.1 & 67.1 & 95.5 \\
\hline TR 52 & 29.6 & 78.1 & 93.1 & 136.9 & 18.1 & 53.5 & 75.4 \\
\hline Gapp 596 & 35.4 & 92.7 & 132.0 & 173.9 & 41.6 & 62.2 & 112.4 \\
\hline TR 09 & 28.5 & 79.0 & 135.0 & 170.5 & 42.0 & 65.8 & 82.1 \\
\hline $\begin{array}{l}\text { Significance } \\
\text { LSD }\end{array}$ & NS & NS & $\begin{array}{c}p<0.01 \\
26.4\end{array}$ & $\begin{array}{c}p<0.01 \\
38.3\end{array}$ & $\begin{array}{c}p<0.001 \\
8.5\end{array}$ & $\begin{array}{c}p<0.001 \\
11.7\end{array}$ & $\begin{array}{c}p<0.001 \\
15.7\end{array}$ \\
\hline
\end{tabular}

* NS, not significant; LSD, least significant difference $(p<0.05)$.

Table 3 - Stolon growing rates in white clover germplasm during the reproductive stage. Values averaged all over the season.

\begin{tabular}{|c|c|c|c|c|c|c|c|}
\hline \multirow[b]{2}{*}{ Germplasm } & \multicolumn{4}{|c|}{ Spring } & \multicolumn{3}{|c|}{ Summer } \\
\hline & $\begin{array}{c}\text { Oct. } \\
13-20\end{array}$ & $\begin{array}{c}\text { Oct. } \\
21-27 \\
\end{array}$ & $\begin{array}{c}\text { Oct. } 28- \\
\text { Nov. } 3\end{array}$ & Nov. $4-10$ & Dec. $22-30$ & $\begin{array}{c}\text { Dec. } 31- \\
\text { Jan. } 6\end{array}$ & Jan. 7-13 \\
\hline & $-\cdots$ & - & 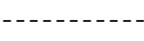 & DM per $g$ & int per day - & $\cdots-\cdots$ & - \\
\hline $\begin{array}{l}\text { Lucero P. } \\
\text { INTA }\end{array}$ & 5.0 & 7.4 & 9.4 & 7.7 & 6.3 & 6.3 & 10.0 \\
\hline Haifa & 6.2 & 7.8 & 8.3 & 9.2 & 2.7 & 5.4 & 5.00 \\
\hline G. Kopu & 5.9 & 6.2 & 6.1 & 8.9 & 3.6 & 4.3 & 2.1 \\
\hline TR 38 & 5.3 & 7.9 & 5.9 & 5.8 & 5.2 & 5.4 & 4.4 \\
\hline Espanso & 4.6 & 6.1 & 5.9 & 7.5 & 4.8 & 5.0 & 6.6 \\
\hline TR 52 & 4.5 & 6.9 & 2.2 & 6.2 & 2.3 & 5.5 & 3.6 \\
\hline Gapp 596 & 5.2 & 8.2 & 5.6 & 6.0 & 5.4 & 4.3 & 10.0 \\
\hline TR 09 & 4.1 & 7.2 & 8.0 & 5.2 & 5.5 & 5.4 & 5.0 \\
\hline $\begin{array}{l}\text { Significance } \\
\text { LSD }\end{array}$ & NS & NS & $\begin{array}{c}p<0.01 \\
2.6\end{array}$ & NS & $\begin{array}{c}p<0.001 \\
1.1\end{array}$ & NS & $\begin{array}{c}p<0.001 \\
0.21\end{array}$ \\
\hline
\end{tabular}

*NS, not significant; LSD, least significant difference $(p<0.05)$. 
Table 4 - Path coefficients and indirect effects for white clover stolon growing rates and two predictor variables in spring and summer.

\begin{tabular}{|c|c|c|c|c|c|c|c|}
\hline \multirow{2}{*}{ Pathway } & \multicolumn{4}{|c|}{ Spring } & \multicolumn{3}{|c|}{ Summer } \\
\hline & Oct. $13-20$ & Oct. 21-27 & Oct. 28 -Nov. 3 & Nov. 4-10 & Dec. $22-30$ & Dec. $31-J a n .6$ & Jan. 7-13 \\
\hline \multicolumn{8}{|l|}{ lar vs. sgr } \\
\hline Direct effect of lar & 0.60 & 0.51 & 0.66 & 0.38 & 0.57 & 0.66 & 0.19 \\
\hline Indirect effect via la & 0.01 & -0.29 & 0.14 & -0.06 & -0.08 & -0.24 & -0.001 \\
\hline Indirect effect via iar & -0.10 & 0.21 & -0.003 & 0.001 & 0.25 & -0.13 & -0.02 \\
\hline Indirect effect via iw & 0.38 & -0.07 & -0.001 & 0.03 & -0.02 & -0.02 & 0.11 \\
\hline Total correlation & 0.89 & 0.36 & 0.80 & 0.35 & 0.72 & 0.27 & 0.28 \\
\hline \multicolumn{8}{|l|}{ la vs. sgr } \\
\hline Direct effect of la & 0.85 & 0.86 & 0.48 & 0.63 & 0.35 & 0.60 & 0.22 \\
\hline Indirect effect via lar & -0.07 & -0.07 & 0.19 & -0.04 & -0.36 & -0.27 & -0.001 \\
\hline Indirect effect via iar & -0.01 & -0.04 & 0.01 & -0.02 & -0.08 & 0.10 & 0.26 \\
\hline Indirect effect via iw & -0.04 & -0.05 & 0.01 & 0.02 & 0.12 & -0.03 & 0.10 \\
\hline Total correlation & 0.73 & 0.60 & 0.69 & 0.59 & 0.03 & 0.40 & 0.58 \\
\hline \multicolumn{8}{|l|}{ iar vs. sgr } \\
\hline Direct effect of iar & 0.03 & 0.17 & -0.04 & -0.11 & 0.41 & 0.37 & 0.62 \\
\hline Indirect effect via lar & 0.14 & 0.16 & 0.06 & -0.02 & -0.35 & -0.23 & -0.01 \\
\hline Indirect effect via la & -0.11 & -0.23 & -0.10 & 0.13 & -0.07 & 0.16 & 0.09 \\
\hline Indirect effect via iw & 0.03 & 0.10 & -0.01 & -0.03 & 0.01 & 0.02 & 0.08 \\
\hline Total correlation & 0.09 & 0.20 & -0.09 & -0.03 & 0.00 & 0.32 & 0.78 \\
\hline \multicolumn{8}{|l|}{ iw vs. sgr } \\
\hline Direct effect of iw & -0.09 & -0.22 & -0.02 & -0.14 & 0.30 & -0.09 & 0.26 \\
\hline Indirect effect via lar & 0.18 & -0.16 & 0.04 & -0.08 & -0.04 & 0.12 & 0.08 \\
\hline Indirect effect via la & 0.38 & -0.07 & -0.001 & 0.03 & -0.02 & -0.02 & 0.09 \\
\hline Indirect effect via iar & -0.01 & -0.08 & -0.01 & -0.02 & 0.09 & 0.07 & 0.20 \\
\hline Total correlation & 0.46 & -0.53 & 0.01 & -0.21 & 0.33 & 0.08 & 0.63 \\
\hline
\end{tabular}

lar = leaf appearance rate (leaves per growing point per week); iar = inflorescence appearance rate (flowers per growing point perweek); la $=$ leaf area $\left(\mathrm{cm}^{2}\right.$ per leaf); iw = inflorescence weight ( $\mathrm{mg}$ DM per inflorescence); sgr = stolon growing rate (mg DM per growing point per day).

net accumulation (Table 2). Also, TR 09, a population with high partition to reproductive sinks and low leaf growth rate, showed a low dry matter net accumulation. On the other hand, germplasm with faster growth had high leaf and flower appearance rates (vg Haifa and Lucero Plus INTA) (Table 1). For breeding work, the results suggested the possibility of getting both, high rates of leaf growth and inflorescence production in spring.

In summer, the highest value of DM net accumulation was obtained with Lucero Plus INTA, and the lowest values with G. Kopu, Haifa and TR 52 (Table 2). Stolon growing rates rose from $4.5 \mathrm{mg}$ DM per growing point per day in the first measurement period to $5.9 \mathrm{mg} \mathrm{DM}$ per growing point per day at the end of the same period (Table 3). There were differences at all dates, and Lucero Plus INTA and Gapp 596 had the highest values, and TR 52 and G. Kopu, the lowest ones ( $7.04 \mathrm{vs} 3.57 \mathrm{mg}$ DM per growing point per day, $p<0.001)$. Path analysis results showed that leaf and inflorescence appearance rate and leaf area were the variables that had the greatest direct effect on stolon growth rate (Table 4). These results provide additional information about the magnitude of the contribution of reproductive structures to stolon growth in spring and summer (Scheneiter \& Pagano, 2001). Hence, reproductive structures should be considered when growth rate is evaluated in different white clover germplasm.

\section{Vegetative stage}

\section{Leaf appearance rate and leaf area}

In autumn, no differences were detected in leaf appearance rate among treatments (Table 5) in agreement with Elgersma \& Li (1997). However, the average value of the season (0.94 leaf per growing 
point per week), due to favorable growing conditions in our experiment was higher than reported by these authors. In winter, Lucero P. INTA, Haifa and TR 38 had higher values than G. Kopu and TR 09. In a previous work, Davies \& Evans (1981) did not detect differences in leaf appearance rate in the coldest months but they did in the warmer ones.

Leaf area was higher in autumn than in other seasons, and cvs Haifa and G. Kopu had average higher leaf area than Lucero P. INTA, TR 09 and TR 38 (Table 5). In winter, leaf area was lower than in autumn and no differences among treatments were detected. The small size of leaves in winter was stated earlier but with differences among germplasm (Davies \& Evans, 1981).

\section{Dry matter (DM) accumulation}

In autumn, cvs Espanso, Haifa and Lucero Plus INTA accumulated more DM per growing point than the other treatments (Table 6). Stolon growing rate was $4.4 \mathrm{mg}$ MS per growing point per day until May $3^{\text {rd }}$, and decreased at the end of the measurement period (Table 7). There were differences among germplasm and cessation of growth of TR 38 at the end of the period became evident. In two of three measurements, leaf area was the variable with higher direct effect on stolon growing rate (Table 8).

In winter, Lucero Plus INTA, and G. Kopu had the highest and lowest net DM accumulation in mid measurement period, respectively (Table 6). Stolon growing rate was $0.5 \mathrm{mg}$ DM.growing point $^{-1}$ day $^{-1}$ in the first week and rose to $4.1 \mathrm{mg} \mathrm{DM}$ per growing point per day in the third week (Table 7). Small differences among treatments were detected only at the beginning of the measurement period. Path analysis results showed that leaf area, on average, had a higher direct effect on stolon grow-

Table 5 - Leaf appearance rate (leaves per growing point per week) and leaf area $\left(\mathrm{cm}^{2}\right.$ per leaf) in white clover germplasm during the vegetative period.

\begin{tabular}{|c|c|c|c|c|}
\hline \multirow{2}{*}{ Germplasm } & \multicolumn{2}{|c|}{ Autumn } & \multicolumn{2}{|c|}{ Winter } \\
\hline & Leaf appearance rate & Leaf area & Leaf appearance rate & Leaf area \\
\hline Lucero Plus INTA & 1.07 & 5.2 & 0.67 & 3.8 \\
\hline Haifa & 0.95 & 6.2 & 0.67 & 3.2 \\
\hline G. Kopu & 0.91 & 6.2 & 0.57 & 2.5 \\
\hline TR 38 & 0.95 & 5.1 & 0.67 & 3.6 \\
\hline Espanso & 0.90 & 5.9 & 0.57 & 4.0 \\
\hline TR 52 & 0.88 & 5.8 & 0.63 & 3.8 \\
\hline Gapp 596 & 0.93 & 5.4 & 0.57 & 3.3 \\
\hline TR 09 & 0.93 & 5.2 & 0.55 & 3.4 \\
\hline $\begin{array}{l}\text { Significance } \\
\text { LSD }\end{array}$ & NS & $\begin{array}{c}p<0.05 \\
0.9\end{array}$ & $\begin{array}{c}p<0.05 \\
0.08\end{array}$ & NS \\
\hline
\end{tabular}

*NS, not significant; LSD, least significant difference $(p<0.05)$.

Table 6 - Dry matter net accumulation in autumn and winter with different white clover germplasm (mg DM per growing point).

\begin{tabular}{lccccccc}
\hline \multirow{2}{*}{ Germplasm } & \multicolumn{3}{c}{ Autumn } & & \multicolumn{3}{c}{ Winter } \\
\cline { 2 - 5 } \cline { 7 - 8 } & Apr. 22-28 & Apr. 29-May 4 & May 5-11 & & Jul. 14-20 & Jul. 21-27 & Jul. 28-Ago. 3 \\
\hline Lucero P. INTA & 28.4 & 59.3 & 70.3 & & 5.1 & 31.6 & 64.3 \\
Haifa & 39.0 & 64.1 & 70.3 & & 3.7 & 26.0 & 51.9 \\
G. Kopu & 27.3 & 55.4 & 58.1 & & 2.4 & 18.6 & 45.6 \\
TR 38 & 29.6 & 53.7 & 52.5 & & 4.3 & 27.1 & 55.9 \\
Espanso & 31.7 & 56.6 & 75.8 & & 3.7 & 29.3 & 63.7 \\
TR 52 & 33.0 & 51.3 & 60.4 & & 4.6 & 26.0 & 67.5 \\
Gapp 596 & 29.3 & 52.1 & 58.7 & & 1.7 & 24.5 & 58.7 \\
TR 09 & 27.8 & 45.8 & 56.3 & & 1.2 & 27.2 & 63.1 \\
Significance & $p<0.001$ & $p<0.001$ & $p<0.001$ & & $p<0.001$ & $p<0.05$ & NS \\
LSD & 3.3 & 5.5 & 10.4 & & 1.53 & 7.22 & \\
\hline
\end{tabular}

*NS, not significant; LSD, least significant difference $(p<0.05)$. 
Table 7 - Stolon growing rates (mg DM per growing point per day) in white clover germplasm during the vegetative stage.

\begin{tabular}{|c|c|c|c|c|c|c|}
\hline \multirow{2}{*}{ Germplasm } & \multicolumn{3}{|c|}{ Autumn } & \multicolumn{3}{|c|}{ Winter } \\
\hline & Apr. 22-28 & Apr. 29-May 4 & May 5-11 & Jul. $14-20$ & Jul. 21-27 & Jul. 28-Ago. 3 \\
\hline Lucero P. INTA & 4.1 & 5.2 & 1.6 & 0.7 & 3.8 & 4.1 \\
\hline Haifa & 5.6 & 4.2 & 0.9 & 0.5 & 3.2 & 3.2 \\
\hline G. Kopu & 3.9 & 4.7 & 0.4 & 0.3 & 2.3 & 3.4 \\
\hline TR 38 & 4.2 & 4.0 & -0.2 & 0.6 & 3.2 & 3.6 \\
\hline Espanso & 4.5 & 4.2 & 2.7 & 0.5 & 3.7 & 4.3 \\
\hline TR 52 & 4.7 & 3.0 & 1.3 & 0.7 & 3.1 & 5.2 \\
\hline Gapp 596 & 4.2 & 3.8 & 0.9 & 0.3 & 3.3 & 4.3 \\
\hline TR 09 & 4.0 & 3.0 & 1.5 & 0.2 & 3.7 & 4.5 \\
\hline $\begin{array}{l}\text { Significance } \\
\text { LSD }\end{array}$ & $\begin{array}{c}p<0.001 \\
0.5\end{array}$ & $\begin{array}{c}p<0.01 \\
1.0\end{array}$ & $\begin{array}{c}p<0.05 \\
1.5\end{array}$ & $\begin{array}{c}p<0.001 \\
0.2\end{array}$ & NS & NS \\
\hline
\end{tabular}

*NS, not significant; LSD, least significant difference $(p<0.05)$.

Table 8 - Path coefficients and indirect effects for white clover stolon growing rates and two predictor variables in the autumn and winter.

\begin{tabular}{|c|c|c|c|c|c|c|}
\hline \multirow{2}{*}{ Pathway } & \multicolumn{3}{|c|}{ Autumn } & \multicolumn{3}{|c|}{ Winter } \\
\hline & Apr. 22-28 & Apr. 29-May 4 & May 5-11 & Jul. 14-20 & Jul. 21-27 & Jul. 28-Ago. 3 \\
\hline \multicolumn{7}{|l|}{ lar vs. sgr } \\
\hline Direct effect of la & 0.46 & 0.63 & 0.47 & 0.85 & 0.38 & 0.22 \\
\hline Indirect effect via la & -0.19 & -0.31 & -0.09 & -0.20 & 0.002 & -0.02 \\
\hline Total correlation & 0.27 & 0.32 & 0.38 & 0.65 & 0.38 & 0.20 \\
\hline \multicolumn{7}{|l|}{ la vs. sgr } \\
\hline Direct effect of la & 0.79 & 0.79 & 0.46 & 0.67 & 0.78 & 0.84 \\
\hline Indirect effect via lar & -0.33 & -0.39 & -0.09 & -0.16 & 0.004 & -0.08 \\
\hline Total correlation & 0.46 & 0.40 & 0.37 & 0.51 & 0.78 & 0.76 \\
\hline
\end{tabular}

lar $=$ leaf appearance rate (leaves per growing point perweek) $1 \mathrm{la}=$ leaf area $\left(\mathrm{cm}^{2}\right.$ per leaf); $\mathrm{sgr}=$ stolon growing rate $(\mathrm{mg}$ DM per growing point per day).

ing rates than leaf appearance rate (Table 8). Also, Davies \& Evans (1981) determined that changes in size of leaves were the principal variable that accounted for changes in dry weight of white clover swards. In addition, leaf size rather than stolon characteristics, is an important variable to be consider for the success of white clover in mixtures with grass species (Elgersma \& Li, 1997). Hence, seasonal differences in leaf area related to DM accumulation of white clover germplasm should be considered while mixing with other species and in the defoliation pattern.

\section{CONCLUSIONS}

White clover had different seasonal mechanisms for DM accumulation, a characteristic that enhances the breeding work due to differences in germplasm performance in each season. Leaf area, more than leaf appearance rate, is the variable with most differences among germplasm and mostly re- lated to DM accumulation. However, in spring and summer, inflorescence production has important effects on growing stolon rate, and differences among germplasm are evident. This is an important attribute, not only for DM accumulation and quality, but also for seed production in future cultivars.

DM accumulation was higher in commercial cultivars than in local populations thus showing the selection performed by forage breeders. However, some local populations exhibited some favorable attributes that could be useful for breeding.

\section{ACKNOWLEDGEMENTS}

The authors are grateful to Andrés Codaro, Sergio Fontana and Juan Carlos Parra for trail maintenance and technical assistance and, Ezio Maiola for his invaluable assistance in English translation. 


\section{REFERENCES}

ACUÑA, R.H.; FIGUEROA, R.M; OLIVARES-B., S. Determinación de las tasas de aparición y de elongación de hojas de ballica perenne (Lolium perenne L.) y de aparición de hojas de trébol blanco (Trifolium repens L.) en la zona centro sur de Chile. Agro-ciencia, v.3, p.257-283, 1997.

BERTÍN, O.D. Evaluación de materiales genéticos de trébol blanco en la producción forraje y semilla. Carta Acuerdo INTA/EEA Pergamino-Gapp: informe final. Pergamino: INTA/EEA, 2002. $9 \mathrm{p}$

CARADUS, J.R.; WOODFIELD, D.R. World checklist of white clover varieties. II. New Zealand Journal of Agricultural Research, v.40, p.115-206, 1997.

DAVIES, A.; EVANS, M.L. The pattern of growth in swards of two contrasting varieties of white clover in winter and spring. Grass and Forage Science, v.37, p. 199-207, 1981

DOFING, M.S.; KNIGHT, C.W. Alternative model for path analysis of small-grain yield. Crop Science, v.32, p.487-489, 1992.

ELGERSMA, A.; LI, F. Effects of cultivar and cutting frequency on dynamics of stolon growth and leaf appearance in white clover in mixed swards. Grass and Forage Science, v.52, p.370$380,1997$.

FRAME, J. White clover. In: FRAME, J.; CHARLTON, J.F.L.; LAIDLAW, A.S. (Ed.) Temperate forage legumes. Wallingford: CABI, 1998. p.15-106.

HILL, M.J.; PEARSON, C.J.; KIRBY, A.C. Germination and seedling growth of prairie grass, tall fescue and Italian ryegrass at different temperatures. Australian Journal of Agricultural Research, v.36, p.13-24, 1985.

LAWSON, A.R.; SALE, P.W.G.; KELLY, K.B. Effect of defoliation frequency on an irrigated perennial pasture in northern Victoria. 2. Individual plant morphology. Australian Journal of Agricultural Research, v.48, p.819-29, 1997.

PAGANO, E.M. Novedad: primer cultivar sintético nacional de trébol blanco: "Lucero Plus INTA". Revista de Tecnología Agropecuaria, v. 4, p.13, 1999.
PAGANO, E.M.; SCHENEITER, J.O. Características y comportamiento del nuevo cultivar de trébol blanco Lucero Plus INTA. Revista de Tecnología Agropecuaria, v.5, p.2932,2000

ROSSO, B.S.; PAGANO, E.M. Collection and characterization of naturalized populations of white clover (Trifolium repens L.) in Argentina. Genetic Resources and Crop Evolution, v.48, p.513-517, 2001a.

ROSSO, B.S.; PAGANO, E.M. Modelos de floración y producción de inflorescencias de trébol blanco: comportamiento de diferentes cultivares. INTA. Estación Experimental Agropecuaria Pergamino. Revista de Tecnología Agropecuaria, v.6, p.3941, 2001b.

SAS INSTITUTE. SAS/STAT: users guide; version 6.4 ed. Cary:,SAS Institute, 1989. v.1, 943p.

SCHENEITER, J.O.; PAGANO, E.M. Stolon growth and its morphological components in white clover (Trifolium repens L.) cultivars. In: INTERNATIONAL GRASSLAND CONGRESS, 19., Sao Pedro, 2001. Proceedings. Piracicaba: FEALQ, 2001. p.576-577.

THOMAS, R.G. Reproductive development. In: BAKER, M.J.; WILLIAMS, W.M. (Ed.) White clover. Wallinford: CABI, 1987. p.63-123.

WILLIAMS, R.F.; EVANS, L.T.; LUDWIG, L.J. Estimation of leaf area for clover and Lucerne. Australian Journal of Agricultural Research, v.15, p.231-233, 1964.

WILLIAMS, W.A.; JONES, M.B.; DEMMENT, M.W. A concise table for path analysis statistics. Agronomy Journal, v.82, p.1022-1024, 1990.

WOODFIELD, D.; CARADUS, J.R. Genetics improvement in white clover representing six decades of plant improvement. Crop Science, v.34, p.1205-1213, 1994.

Received March 13,2007

Accepted October 31, 2008 